Comparative Biochemistry and Physiology Part C: Pharmacology, Toxicology and

Endocrinology Volume 123, Issue 3, July 1999, Pages 217-223

\title{
Eicosanoids mediate nodulation reactions to bacterial infections in larvae of the butterfly, Colias eurytheme
}

\author{
David W Stanley, W Wyatt Hoback, Jon C Bedick, Hasan Tunaz, Rico L Rana, A.R Nor Aliza, \\ Jon S Miller
}

\begin{abstract}
Nodulation is the first, and qualitatively predominant, cellular defense reaction to bacterial infections in insects. Treating larvae of the butterfly Colias eurytheme with the eicosanoid biosynthesis inhibitor dexamethasone, strongly impaired nodulation reactions to bacterial infections. The influence of dexamethasone was reversed by treating infected insects with arachidonic acid, an eicosanoid precursor. An eicosanoid biosynthesis system in C. eurytheme larvae is documented. Specifically, the presence of eicosanoid-precursor polyunsaturated fatty acids in tissue phospholipids was determined, an intracellular phospholipase $\mathrm{A}_{2}$ that can release arachidonic acid from tissue phospholipids was recorded, and eicosanoid biosynthesis, registered as conversion of exogenous radioactive 20:4n-6 into eicosanoids, was observed. These findings support the hypothesis that eicosanoids mediate cellular immune responses to bacterial infections in these butterfly larvae, and more broadly, in most, if not all, insects.
\end{abstract}

Keywords: Butterfly larvae; Colias eurytheme; Insect immunity; Nodulation; Eicosanoids 